\title{
The Determinants of Corporate Cash Holdings: The Case of a Small Emerging Market
}

\author{
Ghada Tayem ${ }^{1}$ \\ ${ }^{1}$ Assistant Professor of Finance, School of Business, The University of Jordan, Amman, Jordan \\ Correspondence: Ghada Tayem, School of Business, The University of Jordan, Amman 11942, Jordan. Tel: \\ 962-6-53-55000.
}

Received: September 10, 2016

Accepted: December 20, $2016 \quad$ Online Published: January 11, 2017

doi:10.5430/ijfr.v8n1p143

URL: http://dx.doi.org/10.5430/ijfr.v8n1p143

\begin{abstract}
This study investigates the factors influencing the level of corporate cash holdings in the context of Jordan, a small emerging market characterized by large market frictions. This article employs the framework of the trade off, financing hierarchy, and managerial discretion theories to predict determinants of cash reserves. Then it examines these predictions using a sample of listed nonfinancial Jordanian firms over the period 2005-2013 using alternative estimation methods. Consistent with the trade-off theory, the results show that firm size and cash substitutes have negative and significant impact on cash holdings while growth opportunities and cash flow volatility have positive and significant impact. In addition, and consistent with the financing hierarchy view, the results show that cash flow and growth opportunities have positive and significant impact on cash holdings. Also, the study documents that leverage is negatively related to cash holdings while squared leverage is positively related to cash reserves. Finally, the results indicate that there are significant dynamic effects in determining cash holding targets.
\end{abstract}

JEL classification: G30; G32

Keywords: cash holdings, trade-off, financing hierarchy, managerial discretion, Jordan, emerging markets

\section{Introduction}

The size of liquid assets and cash holdings on corporate balance sheets generated an interest in investigating firms' motives to accumulate cash. Empirical studies from different economies around the world show that the size of cash holdings relative to total assets is large. For example, the average cash ratio is 17\% in the US (Opler, Pinkowitz, Stulz, \& Williamson, 1999), 9.9\% in the UK (Ozkan \& Ozkan, 2004), 8\% in Spain (García-Teruel \& Martínez-Solano, 2008), and $9.1 \%$ in Turkey (Uyar \& Kuzey, 2014) to name a few. In perfect capital markets holding cash is irrelevant as firms can meet their shortages of internal funds by raising outside funds at zero costs immediately (Denis, 2011). However, in imperfect capital markets, accumulating cash involves costs and benefits and hence the size of cash holdings may affect the value of the firm (Opler et al., 1999). The literature proposes several views to explain the observed level of cash holdings. These views are consistent with the trade-off (Opler et al., 1999), financing hierarchy (Myers \& Majluf, 1984) and managerial discretion and free cash flow (Jensen, 1986) theories. In this paper I document the level of corporate cash holdings of listed Jordanian companies during the period 2005-2013. In addition, I investigate the determinants of these holdings by using the framework suggested by the three above-mentioned theories. Examining this issue in the context of Jordan, a small emerging market, is useful because capital market imperfections exacerbate in such markets and therefore are expected to have considerable influence on firms' choices of holding cash.

The trade-off theory suggests that value maximizing firms should trade-off the marginal costs and benefits of holding cash when they choose the optimal level of cash holdings. Liquid assets generate low yield and are subject to tax disadvantages (Opler et al., 1999). Also, excessive levels of cash may increase the agency costs (Jensen, 1986; Opler et al., 1999). Nonetheless, the firm has two cost-reduction motives to hold cash: the transaction and precautionary motives (Keynes, 1936). Transaction motive for holding cash relates to the firm's desire to save costs resulting from shortages of internal funds including costs of issuing external financial claims, selling assets and cutting dividends (Opler et al., 1999). For example, a firm facing sudden liquidity shortages can obtain external funds but it will have to incur both fixed and variable issuance costs. The precautionary motive is more related to forgone investment opportunities. Firms facing financial constraints can find external sources of financing unavailable or excessively costly, and therefore, they rely on internal sources of financing instead (Myers \& Majluf, 1984; Myers, 1984). Firms 
can save cash flows into cash and use the latter as a buffer between retained earnings and investment (Kim, Mauer, \& Sherman, 1998; Opler et al., 1999; Pinkowitz \& Williamson, 2001; Ferreira \& Vilela, 2004). In this study, I expect firms to hold significantly higher levels of liquid assets when they face higher costs of external financing (transaction and precautionary). Large firms are subject to lower transaction costs because of the economies of scale (Opler et al., 1999), firms with growth opportunities are subject to greater information asymmetries and hence may decline profitable opportunities (Myers \& Majluf, 1984), firms with volatile earnings face larger transaction costs (Ozkan \& Ozkan, 2004), and dividend-paying firms or firms with large net working capital (NWC) can cut dividends or liquidate NWC at low costs to provide liquidity (Opler et al., 1999). This study hypothesizes that firm size, dividends, and cash substitutes are negatively related to cash holdings, while growth opportunities and riskiness of cash flows are positively related to cash holdings.

The above discussion suggests that value-maximizing firms trade-off the costs and benefits of accumulating cash when it decides the level of cash holdings. However, under the managerial discretion view, managers and controlling shareholders may prefer to hold too much cash, more than what required to maximize the value of the firm, because liquid assets reduce the firm's risk and increase their discretion (Opler et al., 1999). Free cash flows increase the power of managers due to the existence of more "unmonitored" resources under their control (Jensen, 1986). Unlike internal funds, external sources of financing are monitored by market participants and hence it is less likely that managers can use external funds to finance negative present value projects. In addition, it is less costly to turn liquid assets into private benefits compared to other assets (Myers \& Rajan, 1998). Listed Jordanian firms are characterized by the existence of large controlling shareholders. Therefore, we would expect that in the context of Jordan, firms with large controlling shareholders will accumulate large cash holdings.

The alternative view of cash focuses on financing hierarchy explanation of cash holdings. Firms facing information asymmetries avoid issuing information-sensitive securities because of the high costs of adverse selection. Instead, they maintain a surplus of internal funds that can be used when firms face internal funds deficit (Myers \& Majluf, 1984). Under this view of cash holdings, changes in a firm's cash flow drives changes in a firm's cash holding (Opler et al., 1999). Therefore, in this study I examine the impact of cash flows on the level of cash holdings with the expectation that cash flows are positively related to cash holdings. In addition, this view implies that firms with large investment opportunity sets are likely to face greater adverse selection because of the difficulty of valuing growth opportunities. Therefore, firms with larger growth opportunities are likely to accumulate more cash. Hence, and similar to the trade-off view prediction, growth opportunities are expected to be negatively related to cash.

This study examines the determinants of cash holdings of nonfinancial Jordanian firms listed on the Amman Stock Exchange (ASE) over the period 2005-2013. The study employs three well-known explanations of cash holdings as a framework to study the determinants of cash holdings: the trade-off theory, managerial discretion and financing hierarchy. The results of this study show that, consistent with the trade-off theory, small firms subject to large transaction costs accumulate more cash holdings in comparison to large firms. In addition, the study finds that growth opportunities and cash flow variability are positively related to cash holdings. This evidence suggests that firms subject to larger information asymmetry are likely to face financing constraints and hence are better off saving cash. Moreover, this study examines the costs of financial distress on accumulating cash by introducing squared leverage into the model specification. At low level of debt, leverage and cash holdings are negatively related as leverage substitutes cash holdings and at high level of debt they are positively related as firms with high leverage have incentives to accumulate large cash holdings to reduce costs of bankruptcy. The results show that squared leverage is positively and significantly related to cash holdings. In addition, the results show that cash flow rights of the largest owner is not significantly related to cash holdings. This evidence is inconsistent with the managerial discretion view of cash holdings. However, this evidence should not be viewed as conclusive because this study does not control for the confounding effects of other governance mechanisms. Finally, this study finds a strong support for the financing hierarchy view. The results show that there is a positive and significant impact of cash flows on cash holdings.

This study contributes to the extant literature on the determination of cash holdings by examining the views of cash holdings in the context of Jordan, a small emerging market. Examining this issue in the context of a small emerging market is interesting because capital market imperfections exacerbate in such markets and therefore are expected to have a considerable influence on a firm's choices of financing. For example, in the case of Jordan, firms rarely issue new external financing through the capital market. Therefore, Jordanian firms are expected to have high propensity to save cash flows into cash that can be used for their future financing needs. 
The rest of the paper is organized as follows. The next section reviews the literature on cash holding determinants. Section 3 presents research model and data is described in Section 4. The results and analysis are discussed in section 5 and the conclusion is presented in Section 6.

\section{Determinates of Cash Holdings}

The literature suggests several variables based on the trade-off, financing, and managerial discretion views of cash holdings, that capture the firm's motives for accumulating cash. These variables are explained next.

\subsection{Size}

According to the trade-off view of cash holdings, large firms enjoy economies of scale when they issue external financing as they can distribute the fixed cost component of issuing external funds over a large size of funds (Smith \& Warner, 1979). In addition, small firms are subject to greater information asymmetry compared to large firms and, therefore are more likely to be financially constrained (Fazzari \& Petersen, 1993). Furthermore, small firms are less diversified and hence are more likely to experience bankruptcy (Titman \& Wessels, 1988). Therefore, small firms are more likely to accumulate cash in order to avoid the fixed costs of external financing, substitute for their lower capacity for external financing, and avoid bankruptcy costs. On the other hand, large firms are survivors who had more success in the business and hence they enjoy larger internal resources. Therefore, large firms could accumulate more cash. The empirical evidence shows that smaller firms accumulate large amounts of cash (Opler et al., 1999; Ferreira \& Vilela, 2004; Chen, 2008; and Bigelli \& Sanchez-Vidal, 2012) while other studies document negative but insignificant impact of size on cash holdings (Ozkan \& Ozkan, 2004; Guney, Ozkan, \& Ozkan, 2007; and García-Teruel \& Martínez-Solano, 2008). Following Sufi (2009), size is measured as the natural logarithm of net total assets, net total assets is defined as total assets minus cash.

\subsection{Growth Opportunities}

Explanations based on the trade-off and financing hierarchy views predict a positive relation between growth opportunities and cash holdings. From a trade-off point of view, firms with large growth opportunities and risky debt are likely to be subject to the underinvestment problem. This is because firms would give up profitable projects as the added value from the project will accrue to outstanding debtholders not shareholders (Myers, 1977). Hence, these firms are likely to accumulate cash in order to finance positive NPV projects. In addition, firms with higher growth opportunities incur higher costs of bankruptcy (Harris \& Raviv, 1990) because the values of these firms fall sharply in times of financial distress. Therefore, firms with large investment opportunity sets have incentives to accumulate more cash to avoid costs of financial bankruptcy and financial distress. From a financing hierarchy view, firms choose internal financing over information-sensitive external financing in the presence of information asymmetries (Myers \& Majluf, 1984). Firms avoid issuing information-sensitive securities because the adverse selection costs make these securities very expensive (Myers \& Majluf, 1984). Firms with large growth opportunities are subject to greater information asymmetry which can result in a premium for external financing (Myers \& Majluf, 1984). Therefore, a firm with a large set of growth opportunities is likely to save cash flows into cash in order to avoid a case whereby it will have to forgo profitable investment opportunities because of the high costs of external financing. The empirical evidence shows that firms with growth opportunities accumulate large amounts of cash (Opler et al., 1999; Ferreira \& Vilela, 2004; Ozkan \& Ozkan, 2004; Guney et al., 2007; Chen, 2008; and García-Teruel \& Martínez-Solano, 2008) while other studies document insignificant impact of growth opportunities on cash holdings (Bigelli \& Sanchez-Vidal, 2012). Following Sufi (2009) growth opportunities are measured using the net market to book ratio defined as the market value of equity plus book value of net assets minus book value of equity divided by net assets.

\subsection{Leverage}

Under the financing hierarchy theory, a firm with internal resource surplus uses these resources to repay debt and/or save cash. However, when a firm is in deficit it exhausts its cash savings and/or issue debt. This implies a negative relation between leverage and cash holdings. In addition, Opler et al., (1999) note that firms facing low investment opportunities set have the lowest marginal benefits of holding cash and are also firms that have high leverage. Several empirical studies document a significant negative relation between leverage and cash holdings including Opler et al., (1999), Guney et al. (2007), Ozkan and Ozkan (2004), and Chen (2008) while García-Teruel and Martínez-Solano (2008) document a positive relation. This study measures leverage as the amount of total debt divided by book value of assets.

\subsection{Squared Leverage}

At a lower level of debt firms view cash holdings and leverage as alternatives, but when debt level increases the probability of bankruptcy increases, and therefore, firms have incentives to accumulate cash to avoid bankruptcy costs 
(Guney et al., 2007). This argument implies that the relation between leverage and cash holdings is nonlinear. To capture the nonlinear relation between leverage and cash holdings, this study follows Guney et al. (2007) and introduces squared leverage. I expect a positive relationship between squared leverage and cash holdings.

\subsection{Cash Flow Rights of the Largest Shareholders}

From an agency perspective, free cash flows increase managers' power due to the existence of more resources under their control, which in effect reduces monitoring incurred by capital markets when the firm needs to obtain new capital (Jensen, 1986). Further, Myers and Rajan (1998) argue that it is less costly to turn liquid assets into private benefits compared to other assets. In Opler et al. (1999), the authors suggest that managers prefer holding cash because it reduces the firms' risk, which is beneficial for under-diversified, risk-averse managers, and because it increases their discretion. In the context of Jordan largest shareholders are likely to exercise control over their firms through their voting rights and by assuming managerial responsibilities. Therefore, they may have incentives to follow a high cash holding policy to increase the amount of liquid assets under their control to pursue their own objectives. Moreover, to the extent that leverage puts disciplinary pressures on managers, a policy of low leverage and high cash holdings may be pursued by controlling shareholders in an attempt to resist such disciplinary pressures. Finally, large shareholders in Jordan are under-diversified and are likely to prefer holding cash because it reduces the firms' risk. The argument above implies a positive relation between cash flow rights and cash holdings. The evidence suggests that there is a positive impact of governance quality on cash holdings using international and country specific contexts (see for example Dittmar, Mahrt-Smith, \& Servaes, 2003; Kalcheva \& Lins, 2007; Harford, Mansi, \& Maxwell, 2008; and $\mathrm{Kuan}, \mathrm{Li}, \& \mathrm{Chu}, 2011)$. The variable cash flow rights of the largest shareholders is measured as the percentage shares held by the largest owner who holds $5 \%$ or more of outstanding shares.

\subsection{Cash Flows}

Firms prefer internal to external sources of financing in the presence of information asymmetry (Myers \& Majluf, 1984, Myers, 1984). Therefore, firms with large cash flows will save cash flows into cash which induces a positive relation between cash flows and cash (Opler et al., 1999, Ozkan \& Ozkan, 2004). The empirical evidence document a positive impact of cash flows on cash (Opler et al., 1999; Ferreira \& Vilela, 2004; Ozkan \& Ozkan, 2004; and García-Teruel \& Martínez-Solano, 2008). Cash flows are measured as earnings before interest and taxes and depreciation divided by total assets.

\subsection{Cash Flow Volatility}

According to the trade-off theory firms with more volatile cash flows will be subject to a greater number of states in which the firm will be short of liquid assets (Ozkan \& Ozkan, 2004). Therefore, firms may fail to finance all profitable projects and they face larger costs of external financing (Ozkan \& Ozkan, 2004). Thus, firms with more volatile cash flows are expected to hold more cash in order to reduce the costs of sudden liquidity shortages. The evidence documented in Guney et al., (2007), and Bigelli and Sanchez-Vidal (2012) show that the cash flow volatility is positively related to cash holdings. More recently, Bates, Khale, and Stulz, (2009) document that the increase of cash holdings in the US in the past two decades is driven by the increased volatility associated with the listing of new firms. The volatility of cash flows is measured following the approach in Sufi (2009). It is computed as the standard deviation of annual changes in the level of cash flows (earnings before interest, taxes and depreciation) over a lagged four-year period, scaled by average non-cash assets in the lagged period.

\subsection{Cash Substitutes (Working Capital)}

Opler et al. (1999) suggest that firms use other liquid assets in case of cash shortfalls, implying that these assets substitute cash holdings. Therefore, I expect a negative relation between working capital and cash holdings. Several studies document a negative relation between cash substitutes and cash holdings (Opler et al., 1999; Ferreira \& Vilela, 2004; García-Teruel \& Martínez-Solano, 2008; and Bigelli \& Sanchez-Vidal, 2012). The variable cash substitutes is measured as the difference between current assets minus cash and current liabilities divided by net total assets.

\subsection{Dividend Payments}

The trade-off view predicts a negative relationship between dividend payments and cash holdings. Under this view, dividend cuts can provide funds in case of liquidity shortages. Dividend cuts are assumed to be associated with low costs and hence dividend-paying firms are less likely to accumulated cash in comparison to non-paying firms. Similarly, the financing hierarchy view predicts a negative relationship between dividends and cash holdings. Firms with large investment opportunities who are more likely to save cash should not pay dividends. However, Ozkan and Ozkan (2004) argue that dividend-paying firms could accumulate cash to avoid scenarios where they are short of 
internal cash flows that are insufficient to pay dividends. Dividends are measured by assigning a value of 1 for firm-years paying dividends and zero otherwise.

\subsection{Capital Expenditures}

The trade-off view predicts a positive relationship between capital expenditures and cash holdings. Firms with high growth opportunities invest a lot and hence they hold on average more cash to support their capital expenditures. However, the financing hierarchy view predicts that firms that spend more on capital expenditures have fewer internal resources and hence these firms would accumulate less cash. For the purposes of this study the variable capital expenditures is measured as the change in net fixed assets between two consecutive years divided by capital at the beginning of the period. Guney et al. (2007) and Chen (2008) document a negative relation between capital expenditures and cash holdings, while Opler et al. (2009) document a positive relation.

\subsection{Age}

I include the firm's age as a proxy of information asymmetry as it measures how much the market knows about the firm. Old firms are expected to be more known to the market in comparison to small firms. Therefore, the firm's age is expected to be negatively related to cash holdings (Opler et al., 1999). However, the firm's age indicates how successful a firm is in its business. The older the firm, the more successful it is and the more internal resources it has. Therefore, the firm's age could be positively related to cash holdings. The firm's age is measured as the natural logarithm of the years since the firm's inception.

Operational definitions of the variables discussed so far are presented in Table 1.

Table 1. Summary of variable definitions

\begin{tabular}{|c|c|}
\hline Variable & Proxy \\
\hline $\begin{array}{l}\text { Cash Holding Ratio } \\
\text { (Cash) }\end{array}$ & $\begin{array}{l}\text { Cash shown under current assets divided by net total assets. Net total assets equal total } \\
\text { assets minus cash. }\end{array}$ \\
\hline $\begin{array}{l}\text { Firm size } \\
(\text { Size })\end{array}$ & Natural logarithm of net total assets. \\
\hline $\begin{array}{l}\text { Growth opportunities } \\
(M T B)\end{array}$ & $\begin{array}{l}\text { Net market to book value ratio (MTB) defined as the market value of equity plus book } \\
\text { value of net assets minus book value of equity divided by net assets. }\end{array}$ \\
\hline $\begin{array}{l}\text { Debt Ratio } \\
(\text { Leverage })\end{array}$ & $\begin{array}{l}\text { The total of all long and short term borrowings divided by total assets valued at book } \\
\text { basis. }\end{array}$ \\
\hline $\begin{array}{l}\text { Squared Leverage } \\
(\text { SQ Leverage })\end{array}$ & Leverage squared. \\
\hline $\begin{array}{l}\text { Cash Flow Rights of the } \\
\text { Largest Shareholder } \\
\text { (Largest) }\end{array}$ & $\begin{array}{l}\text { The percentage of shares held by the largest owner who hold } 5 \% \text { or more of outstanding } \\
\text { shares. }\end{array}$ \\
\hline $\begin{array}{l}\text { Cash flows } \\
\text { (Cash Flow) }\end{array}$ & Earnings before interest, tax and deprecation divided by net total assets. \\
\hline $\begin{array}{l}\text { Cash Flows Volatility } \\
\text { (Volatility) }\end{array}$ & $\begin{array}{l}\text { The standard deviation of annual changes in the level of cash flows (earnings before } \\
\text { interest, taxes and depreciation) over a lagged four-year period, scaled by average } \\
\text { non-cash assets in the lagged period. }\end{array}$ \\
\hline $\begin{array}{l}\text { Working Capital } \\
\text { (Cash Substitutes) }\end{array}$ & $\begin{array}{l}\text { The difference between current assets minus cash and current liabilities divided by net } \\
\text { total assets. }\end{array}$ \\
\hline $\begin{array}{l}\text { Dividends Dummy } \\
\text { (Dividends) }\end{array}$ & An indicator variable that takes the value of 1 if the firm pays dividends and 0 otherwise. \\
\hline $\begin{array}{l}\text { Capital Expenditures } \\
\text { (Capital Expenditures) }\end{array}$ & $\begin{array}{l}\text { The change in net fixed assets between two consecutive years divided by capital at the } \\
\text { beginning of the period. }\end{array}$ \\
\hline $\begin{array}{l}\text { Firm Age } \\
(\text { Age })\end{array}$ & The natural logarithm between the fiscal year and the year of a firm's inception. \\
\hline
\end{tabular}


This table summarizes operational definitions of the variables used in the study. Financial data is collected from the Corporate Guides issued by the ASE. Ownership data is collected from the Corporate Guides for the period 2005-2007 and from the financial statements of listed companies thereafter.

\section{Study Methodology}

The aim of this study is to examine the determinants of cash holdings by estimating a cash model specified in equation 1 :

$$
\begin{aligned}
\text { Cash }_{i t}= & \beta_{1} \text { Size }_{i t}+\beta_{2} \text { MTB }_{i t}+\beta_{3} \text { Leverage }_{i t}+\beta_{4} \text { SQLeverge }_{i t}+\beta_{5} \text { Lareg }_{i t}+\beta_{6} \text { Cash Flow }_{i t} \\
& +\beta_{7} \text { Volatility }_{i t}+\beta_{8} \text { Cash Substitutes }_{i t}+\beta_{9} \text { Dividends }_{i t}+\beta_{10} \text { Capital Expenditures }_{i t} \\
& +\beta_{11} \text { Age }_{i t}+e_{i t}
\end{aligned}
$$

Variables are defined in Table 1 . At the primary stage of analysis, equation 1 is estimated using OLS. Nonetheless, the error term $e_{i t}$ in equation 1 contains firm-specific effects $v_{i}$ and the usual idiosyncratic error $v_{i t}$. If firm-specific effects $v_{i}$ are correlated with other control variables this will cause OLS coefficient estimates to be biased and inconsistent. Therefore, equation 1 is modified to take into account the firm's unobservable specific effects that change across firms but are fixed for a given firm through time. This will result in unbiased and consistent estimates of the coefficients (Wooldridge, 2002). This study employs two estimation methods that deal with firm effects: fixed (within) effects that treats $v_{i}$ as fixed and random effects that treats $v_{i}$ as random. In this study, I do not make assumptions about the correlation between the explanatory variables and the unobservable firm effects and hence I employ both estimation methods.

The previous literature frequently uses the static cash holding model with the assumption that firms with a target cash holdings can instantaneously adjust towards that target. However, due to the existence of transaction and other adjustment costs, an adjustment process may take place where the current cash structure will not adjust immediately to a new targeted cash structure (Ozkan \& Ozkan, 2004). To investigate these issues I include a lagged value of cash, Cash $_{i t-l}$, to account for a firm's dynamic adjustment towards an optimal cash holding level. The value of the coefficient captures the fraction of the target change that has been achieved. Deducting that amount from one indicates the degree of the adjustment costs that the firm faces when it moves to its target level. However, when a lagged dependent variable is included as a control variable, it becomes correlated with the error term $v_{i t}$. Therefore, estimating equation 1 in static form using standard panel data techniques leads to biased and inconsistent estimators. In order to overcome this problem, system Generalized Methods of Moments (GMM) is applied by using the levels equation (equation 1) with the lagged dependent variable Cash $_{i t-1}$ to obtain a system of two equations, one differenced and one in levels (Arellano \& Bond, 1991).

\section{Data Sources and Sample Description}

The sample consists of nonfinancial Jordanian companies publicly traded on the ASE over the period 2005-2013. The choice of the sample period is motivated by data availability as the ASE has been reporting financial data regularly through the Company Guides starting from 2002. In addition, the computation of the measure Volatility requires observations from the previous four years and therefore the analysis uses the data from the period 2005-2013. Data on financial items is obtained from the ASE's Company Guides. Company Guides compile financial data items obtained from the financial statements of firms listed in the ASE and is published by the ASE at the end of each year. Data on ownership is collected from the Companies Guide for the period 2005-2007. The 2008 Company Guide edition onwards do not compile ownership data. Therefore, ownership data is collected manually from the firm's annual reports for the period 2008-2013. It is mandated that listed firms on the ASE disclose in their annual reports the names of owners with an equity stock holding equal or above 5\%, the numbers of declared shares and the corresponding percentage of ownership for each owner. The financial, market and ownership data are then matched using the firm's identifier. Firms with less than two consecutive years of complete data items are excluded. The final sample consists of 131 nonfinancial firms. The next table presents some descriptive statistics of the key variables in the study.

Table 2 shows that half of firm-year (thereafter firms) observations hold $2.3 \%$ of their net total assets as liquid cash. Nonetheless, the mean value of Cash is $8 \%$ indicating that some firms have relatively large cash holdings (relative to the median value). For example, the $75^{\text {th }}$ percentile firms report a Cash ratio of $9 \%$ and above. The distribution of cash across years is fairly homogenous during the 2005-2013 period with the average ranging between $7 \%$ low in 2008 and 9.3\% high in 2013 (not reported). 
Table 2. Summary statistics

\begin{tabular}{lrrrrrrr}
\hline & \multicolumn{1}{c}{ Mean } & \multicolumn{1}{c}{ Median } & \multicolumn{1}{c}{ SD } & \multicolumn{1}{c}{ Min } & \multicolumn{1}{c}{ Max } & Skewness & Kurtosis \\
\hline Cash & 0.080 & 0.023 & 0.153 & 0 & 1.241 & 3.705 & 19.177 \\
Size (In) & 16.810 & 16.728 & 1.371 & 12.649 & 21.278 & 0.327 & 3.555 \\
MTB & 1.406 & 1.129 & 0.849 & 0.254 & 5.633 & 1.935 & 7.091 \\
Leverage & 0.151 & 0.110 & 0.154 & 0 & 0.680 & 0.999 & 3.356 \\
SQ Leverage & 0.046 & 0.012 & 0.075 & 0 & 0.463 & 2.519 & 10.228 \\
Largest & 32.049 & 27 & 19.708 & 5.523 & 97.3 & 1.259 & 4.605 \\
Cash Flow & 0.076 & 0.071 & 0.131 & -0.534 & 0.634 & 0.592 & 7.206 \\
Volatility & 0.085 & 0.057 & 0.085 & 0.002 & 0.593 & 2.295 & 9.534 \\
Cash Substitutes & 0.100 & 0.078 & 0.243 & -0.712 & 0.831 & 0.177 & 3.391 \\
Dividends & 0.421 & 0 & 0.494 & 0 & 1 & 0.322 & 1.103 \\
Capital Expenditures & 0.118 & -0.020 & 0.862 & -0.936 & 15.796 & 10.942 & 156.268 \\
Age (Years) & 23.004 & 18 & 15.410 & 1 & 75 & 0.968 & 3.204 \\
\hline
\end{tabular}

Table 2 reports descriptive statistics for a sample of nonfinancial Jordanian firms listed in the ASE over the period 2005-2013. Variables are defined in Table 1.

To examine if there are industry effects, I report the mean and median values of Cash for the 19 sectors (sectors are defined based on the ASE classification) in Table 3. The mean values indicate that there are some industry effects with regard to cash holdings, however, the median values suggest that the average sector effect may be driven by a small number of firms in that sector. The technology and communication sector have the highest average of $41 \%$, however, the high cash ratio in this sector is mainly driven by one company "Jordan Telecom".

Table 3. Distribution of cash across industry sectors

\begin{tabular}{lcc}
\hline \multicolumn{1}{c}{ Sector } & Mean & Median \\
\hline Chemicals & 0.058 & 0.017 \\
Commercial Services & 0.135 & 0.028 \\
Educational Services & 0.057 & 0.009 \\
Electricals & 0.074 & 0.028 \\
Engineering and Construction & 0.028 & 0.007 \\
Food and Beverages & 0.036 & 0.011 \\
Glass and Ceramic & 0.011 & 0.003 \\
Health Care Services & 0.059 & 0.018 \\
Hotels and Tourism & 0.109 & 0.035 \\
Media & 0.121 & 0.040 \\
Mining and Extraction & 0.116 & 0.042 \\
Paper and Cardboard & 0.107 & 0.009 \\
Pharmaceutical and Medical & 0.049 & 0.023 \\
Printing and Packaging & 0.035 & 0.037 \\
Technology and Communications & 0.416 & 0.336 \\
Textiles, Leathers and Clothing & 0.064 & 0.031 \\
Tobacco and Cigarettes & 0.088 & 0.030 \\
Transportation & 0.055 & 0.022 \\
Utilities and Energy & 0.018 & 0.011 \\
\hline
\end{tabular}

Table 3 reports the mean and median values of Cash for the 19 sectors in the ASE. Sectors are defined based on the ASE classification. 
Table 4 presents the correlation coefficients between the variables of the study. Focusing on the correlation coefficients between cash and its expected determinants, we note that most variables carry their expected signs. As hypothesized, growth opportunities (MTB), ownership by the largest owner (Largest), cash flow (Cash Flow) and cash flow volatility (Volatility) are all positively and significantly correlated with Cash. Similarly, Leverage carries the expected negative sign and is significantly correlated with Cash. Dividends is positively correlated with cash indicating that dividend paying firms maintain a reserve of cash in order to sustain their dividends payments in case of cash flow shortfall. However, other expected determinants of cash including, Size, Cash Substitutes, Capital Expenditures, and Age, are not significantly correlated with Cash.

Table 4. Correlation matrix

\begin{tabular}{|c|c|c|c|c|c|c|c|c|c|c|c|c|}
\hline & Cash & Size & MTB & Lev & $\begin{array}{l}\text { SQ } \\
\text { Lev } \\
\end{array}$ & Largest & $\begin{array}{l}\text { Cash } \\
\text { Flow } \\
\end{array}$ & Vol & $\begin{array}{l}\text { Cash } \\
\text { Sub } \\
\end{array}$ & Div & $\begin{array}{l}\text { Cap } \\
\text { Exp } \\
\end{array}$ & Age \\
\hline Cash & 1 & & & & & & & & & & & \\
\hline Size & $\begin{array}{r}0.038 \\
(0.254)\end{array}$ & 1 & & & & & & & & & & \\
\hline MTB & $\begin{array}{l}0.471 \\
(0.00)\end{array}$ & $\begin{array}{r}0.033 \\
(0.322)\end{array}$ & 1 & & & & & & & & & \\
\hline Lev & $\begin{array}{l}-0.164 \\
(0.00)\end{array}$ & $\begin{array}{r}0.078 \\
(0.017)\end{array}$ & $\begin{array}{l}-0.111 \\
(0.001)\end{array}$ & 1 & & & & & & & & \\
\hline SQ Lev & $\begin{array}{l}-0.114 \\
(0.001)\end{array}$ & $\begin{array}{r}0.040 \\
(0.219)\end{array}$ & $\begin{array}{l}-0.072 \\
(0.029)\end{array}$ & $\begin{array}{l}0.914 \\
(0.00)\end{array}$ & 1 & & & & & & & \\
\hline Largest & $\begin{array}{l}0.163 \\
(0.00)\end{array}$ & $\begin{array}{r}0.019 \\
(0.556)\end{array}$ & $\begin{array}{l}0.130 \\
(0.00)\end{array}$ & $\begin{array}{r}0.054 \\
(0.101)\end{array}$ & $\begin{array}{r}0.106 \\
(0.001)\end{array}$ & 1 & & & & & & \\
\hline Cash Flow & $\begin{array}{l}0.471 \\
(0.00)\end{array}$ & $\begin{array}{l}0.324 \\
(0.00)\end{array}$ & $\begin{array}{l}0.485 \\
(0.00)\end{array}$ & $\begin{array}{l}-0.166 \\
(0.00)\end{array}$ & $\begin{array}{l}-0.145 \\
(0.00)\end{array}$ & $\begin{array}{r}0.093 \\
(0.005)\end{array}$ & 1 & & & & & \\
\hline Vol & $\begin{array}{l}0.150 \\
(0.00)\end{array}$ & $\begin{array}{l}-0.081 \\
(0.013)\end{array}$ & $\begin{array}{l}0.183 \\
(0.00)\end{array}$ & $\begin{array}{r}0.059 \\
(0.074)\end{array}$ & $\begin{array}{r}0.061 \\
(0.063)\end{array}$ & $\begin{array}{r}0.095 \\
(0.004)\end{array}$ & $\begin{array}{r}0.013 \\
(0.692)\end{array}$ & 1 & & & & \\
\hline Cash Sub & $\begin{array}{r}0.003 \\
(0.937)\end{array}$ & $\begin{array}{l}-0.294 \\
(0.00)\end{array}$ & $\begin{array}{r}0.030 \\
(0.367)\end{array}$ & $\begin{array}{l}-0.264 \\
(0.00)\end{array}$ & $\begin{array}{l}-0.223 \\
(0.00)\end{array}$ & $\begin{array}{l}-0.178 \\
(0.00)\end{array}$ & $\begin{array}{r}0.064 \\
(0.051)\end{array}$ & $\begin{array}{r}0.017 \\
(0.609)\end{array}$ & 1 & & & \\
\hline Div & $\begin{array}{l}0.194 \\
(0.00)\end{array}$ & $\begin{array}{l}0.284 \\
(0.00)\end{array}$ & $\begin{array}{l}0.231 \\
(0.00)\end{array}$ & $\begin{array}{l}-0.257 \\
(0.00)\end{array}$ & $\begin{array}{l}-0.217 \\
(0.00)\end{array}$ & $\begin{array}{l}-0.111 \\
(0.001)\end{array}$ & $\begin{array}{l}0.508 \\
(0.00)\end{array}$ & $\begin{array}{l}-0.088 \\
(0.008)\end{array}$ & $\begin{array}{l}0.135 \\
(0.00)\end{array}$ & 1 & & \\
\hline Cap Exp & $\begin{array}{r}0.037 \\
(0.268)\end{array}$ & $\begin{array}{l}0.138 \\
(0.00)\end{array}$ & $\begin{array}{r}0.068 \\
(0.040)\end{array}$ & $\begin{array}{r}0.071 \\
(0.033)\end{array}$ & $\begin{array}{r}0.054 \\
(0.102)\end{array}$ & $\begin{array}{r}0.024 \\
(0.472)\end{array}$ & $\begin{array}{r}0.111 \\
(0.001)\end{array}$ & $\begin{array}{r}0.037 \\
(0.261)\end{array}$ & $\begin{array}{l}-0.042 \\
(0.20)\end{array}$ & $\begin{array}{l}0.032 \\
(0.34)\end{array}$ & 1 & \\
\hline Age & $\begin{array}{r}0.048 \\
(0.148)\end{array}$ & $\begin{array}{r}0.092 \\
(0.005)\end{array}$ & $\begin{array}{r}0.073 \\
(0.025)\end{array}$ & $\begin{array}{l}-0.118 \\
(0.00)\end{array}$ & $\begin{array}{l}-0.097 \\
(0.003)\end{array}$ & $\begin{array}{l}-0.026 \\
(0.426)\end{array}$ & $\begin{array}{l}-0.018 \\
(0.592)\end{array}$ & $\begin{array}{l}-0.009 \\
(0.794)\end{array}$ & $\begin{array}{l}0.112 \\
(0.00)\end{array}$ & $\begin{array}{l}0.120 \\
(0.00)\end{array}$ & $\begin{array}{r}-0.052 \\
0.113\end{array}$ & 1 \\
\hline
\end{tabular}

This table shows the correlation between the variables used in the study. Variables are defined in Table 1. $p$-values are in parentheses.

\section{Results and Analysis}

The aim of this paper is to investigate the factors that determine the level of cash holdings of listed Jordanian companies by estimating equation 1 . Table 5 reports the estimation results using four alternative techniques: OLS, fixed effects, random effects, and GMM. All methods use the same specification that includes the following variables: Size, MTB, Leverage, Squared Leverage, Largest, Cash Flow, Cash Flow Volatility, Cash Substitutes, Dividends, Capital Expenditures, and Age. In addition, all specifications include time effects to control for macroeconomic conditions as well as industry effects to control for possible industry variation of using cash. The model is estimated using robust standard errors. 
Table 5. Estimation results of the cash model

\begin{tabular}{|c|c|c|c|c|}
\hline & OLS & Fixed Effects & Random Effects & GMM \\
\hline Constant & $0.167(2.04)^{* *}$ & - & - & - \\
\hline $\operatorname{Cash}_{t-1}$ & - & - & - & $0.570(6.19)^{* * *}$ \\
\hline Size & $-0.016(-2.83)^{* * *}$ & $-0.037(-1.39)$ & $-0.025(-2.03)^{* *}$ & $-0.013(-2.25)^{* *}$ \\
\hline MTB & $0.045(5.29)^{* * *}$ & $0.025(2.18)^{* *}$ & $0.030(2.89) * * *$ & $0.035(3.82)^{* * *}$ \\
\hline Leverage & $-0.282(-3.50) * * *$ & $-0.037(-0.34)$ & $-0.082(-0.81)$ & $-0.277(-3.27) * * *$ \\
\hline SQ Leverage & $0.335(1.71)^{*}$ & $0.087(0.43)$ & $0.121(0.64)$ & $0.462(2.60)^{* * *}$ \\
\hline Largest & $0.015(0.53)$ & $-0.018(-0.30)$ & $-0.002(-0.05)$ & $0.037(0.84)$ \\
\hline Cash Flow & $0.458(5.74)^{* * *}$ & $0.317(4.85)^{* * *}$ & $0.338(5.23) * * *$ & $0.279(3.50)^{* * *}$ \\
\hline Volatility & $0.204(3.14)^{* * *}$ & $0.102(1.56)$ & $0.125(2.31)^{* *}$ & $0.066(0.87)$ \\
\hline Cash Substitutes & $-0.043(-2.27) * *$ & $-0.087(-2.11)^{* *}$ & $-0.076(-2.07) * *$ & $-0.083(-2.68) * * *$ \\
\hline Dividends & $-0.008(-0.81)$ & $0.006(0.82)$ & $0.005(0.65)$ & $0.001(0.07)$ \\
\hline Capital Expenditures & $0.001(1.26)$ & $0.000(0.23)$ & $0.000(0.74)$ & $-0.001(-1.76)^{*}$ \\
\hline Age & $0.016(1.98)^{* *}$ & $0.009(0.26)$ & $0.023(1.71)^{*}$ & $0.009(0.92)$ \\
\hline Time Effects & Yes & Yes & Yes & Yes \\
\hline Industry Effects & Yes & - & Yes & Yes \\
\hline Observations & 932 & 932 & 932 & 776 \\
\hline Groups & 131 & 131 & 131 & 127 \\
\hline $\mathbf{R}^{2}$ & 0.45 & 0.18 & 0.17 & - \\
\hline$F$ Test & & $11.65(0.00)$ & & \\
\hline Hausman Test & & & $35.72(0.011)$ & \\
\hline Hansen Test & & & & $90.24(1.00)$ \\
\hline Arellano-Bond test for $\mathrm{AR}(2)$ & & & & $1.35(0.178)$ \\
\hline
\end{tabular}

Table 5 reports estimation results of the cash model using four alternative estimation methods. The sample consists of nonfinancial Jordanian firms listed in the ASE over the period 2005-2013. Variables are defined in Table 1. $t$-statistics (alternatively $z$-statistics) are in parentheses. $* * *, * *, *$ indicate significance at the $1 \%, 5 \%$, and $10 \%$ respectively.

The estimation results indicate that the first variable of interest, Size, is negatively related to the level of cash holdings. It is significant using all estimation methods except for the fixed effects estimation method. This evidence indicates that small firms accumulate more cash in comparison to large firms. As discussed in Section 2, small firms are subject to larger transaction costs when they issue external financing because they do not enjoy the economies of scale when they issue external financing. In addition, they are subject to larger information asymmetries and bankruptcy costs. Therefore, small firms have incentives to accumulate larger cash holdings, an argument that is supported by the findings. Another variable of interest, $M T B$, is positively related to cash holdings and is significant using all four estimation methods. This result indicates that firms with growth opportunities accumulate larger cash holdings. This finding is consistent with the prediction of the financing hierarchy view. Under this view, firms with growth opportunities are subject to severe information asymmetry problem and therefore issuing information-sensitive securities will be costly as the adverse selection costs are high. To finance their investment set, these firms have incentives to save cash. This finding also supports the trade-off view of cash holdings as firms with large growth opportunities are more likely to be subject to the underinvestment problem and hence they save cash to avoid this problem.

The variables Leverage and Squared leverage have the predicted positive and negative signs respectively. However, these coefficients are significant using the OLS and GMM estimation methods. The results indicate that leverage is negatively related to cash holdings at low level of leverage, however, when leverage increases the impact of leverage on cash holdings reverses. This is because firms with high level of leverage may be subject to larger financial distress costs and hence firms have incentives to accumulate cash in order to reduce these costs. Ownership of the largest shareholder, Largest, has no significant impact on the firm's cash holdings. However, this no-impact result could be due to the fact that this study does not take other governance mechanisms into account. These mechanisms may cancel out the impact of ownership and cause a no impact result. I leave this point for future research. Cash Flow is positive 
and significant in all estimation results. This finding indicates that cash flow surpluses are likely to be saved into cash and cash flow deficits are likely absorbed by cash holdings. This finding is consistent with the financing hierarchy view that predicts that there is no optimal level of cash holdings and that the cash level is closely tied to the fortunes of the firm. Volatility of cash flows is positively related to cash holdings but is significant in only two of the four estimations using OLS and random effects.

The last four variables carry the predicted signs, Cash Substitutes is as predicted negatively and significantly related to Cash, a finding consistent with Opler et al. (1999) observation that liquid assets can substitute cash holdings. Dividends carries a negative sign using OLS and a positive sign using firm effect estimators (within and random) and GMM. However, the impact of dividends is not significant in any of the four models. Capital Expenditures carries a positive sign using OLS and firm effect estimators (within and random) but the relation is insignificant in these models. However, Capital Expenditures is negatively and significantly related to Cash at the 10\% level using the GMM estimation method which indicates that firms with capital expenditures have fewer internal resources and hence they accumulate low cash. Finally, Age is positively and significantly related to cash holdings using OLS and random effects. This result indicates that older firms have more internal resources and hence have fewer incentives to accumulate cash. To account for a firm's dynamic adjustment towards an optimal cash holdings level, I include a lagged term of Cash $_{i t-l}$ in Equation 1 and estimate it using the Arellano and Bond (1991) procedure. Cash it-l $_{\text {is }}$ positive and significantly different from zero at the $1 \%$ significance level which suggests that the dynamic nature of the model is not rejected.

To appreciate the economic importance of the impact of the explanatory variables on cash holdings, I report the marginal impacts of the variables in Table 6 using the OLS estimation results as reference. The marginal impact is computed for each variable assuming it increases from the median value to the $75^{\text {th }}$ percentile holding all other variables constant at the mean value. The largest impacts are caused by changes in Leverage, Cash Flow, MTB, and Size. A firm increasing its leverage from the median to the $75^{\text {th }}$ percentile will result in reducing its Cash by $2.83 \%$ which is a large change given the average value of cash holdings is $8 \%$. This impact calls for further investigation on which type of debt substitute cash and why. I leave this point for future research. Increases in Cash Flow, MTB, and Size from median to $75^{\text {th }}$ percentile lead to 2.57, 2.27, and -1.38 change in Cash. This indicates the important impact of costs of external financing on cash policies of listed Jordanian firms.

Table 6. Marginal impact of coefficients

\begin{tabular}{lc}
\hline & OLS \\
\hline Size & -1.38 \\
MTB & 2.27 \\
Leverage & -2.83 \\
SQ Leverage & 0.44 \\
Largest & 0.22 \\
Cash Flow & 2.57 \\
Volatility & 1.05 \\
Cash Substitutes & -0.75 \\
Dividends & -0.78 \\
Capital & \\
Expenditures & 0.01 \\
Age & 0.84 \\
\hline
\end{tabular}

Table 6 reports the marginal impact of coefficients on Cash when they increase from the median value to the $75^{\text {th }}$ percentile holding all other variables constant at the mean.

\section{Conclusion}

This paper investigates the motives of holding cash of nonfinancial firms listed on the ASE over the period 2005-2013 using the framework of three views of cash holdings: trade-off, financing hierarchy and managerial discretion. Consistent with the trade-off view, the results of this study indicate that listed Jordanian firms hold cash when they face larger transaction costs and large external costs of financing. Smaller firms with high growth opportunities, volatile 
earnings, and low networking capital accumulate significantly large cash reserves. In addition, the results of this paper are consistent with the financing hierarchy view. The findings indicate that cash flows are significantly and positively associated with the level of cash holdings. The results also show that leverage is significantly negatively related to cash holdings which support substitution effect between leverage and cash. Moreover, the results show that squared leverage is positively related to cash holdings. However, the study does not find evidence of an impact of ownership of the largest shareholder on cash holdings. In conclusion, the results point to the importance external costs of financing in shaping a firm's financial policies and they call for more future research on the impact of the type of debt and ownership structures and their interactions on cash holdings.

\section{Acknowledgment}

I would like to thank participants at the Corporate Governance and Finance Workshop (March 2016) organized by the Virtus Global Center for Corporate Governance and the Finance Seminar Series organized by the School of Business/The University of Jordan (Spring 2016) for providing useful comments. I kindly acknowledge the generous financial support received from the Deanship of Academic Research (DAR)/The University of Jordan. The DAR/The University of Jordan had no involvement in the conduct of this research or the preparation of this article. All remaining errors are mine.

\section{References}

Arellano, M., \& Bond, S. (1991). Some Tests of Specification for Panel Data: Monte Carlo Evidence and an Application to Employment Equations. The Review of Economic Studies, 58(2), 277-297. https://doi.org/10.2307/2297968

Bates, T.W., Khale, K.M., \& Stulz, R.M. (2009). Why do US Firms Hold so Much More Cash than they Used to?. The Journal of Finance, 64(5), 1985-2021. https://doi.org/10.1111/j.1540-6261.2009.01492.x

Bigelli, M., \& Sánchez-Vidal, J. (2012). Cash Holdings in Private Firms, Journal of Banking \& Finance, 36(1), 26-35. https://doi.org/10.1016/j.jbankfin.2011.06.004

Chen, Y.-R. (2008). Corporate Governance and Cash Holdings: Listed New Economy versus Old Economy Firms. Corporate Governance: An International Review, 16(5), 430-42. https://doi.org/10.1111/j.1467-8683.2008.00701.x

Denis, D. (2011). Financial Flexibility and Corporate Liquidity. Journal of Corporate Finance, 17(3), 667-674. https://doi.org/10.1016/j.jcorpfin.2011.03.006

Dittmar, A., Mahrt-Smith, J., \& Servaes, H. (2003). International Corporate Governance and Corporate Cash Holdings. Journal of Financial and Quantitative Analysis, 38(1), 111-34. https://doi.org/10.2307/4126766

Fazzari, S.M., \& Petersen, B.C. (1993). Working Capital and Fixed Investment: New Evidence on Financing Constraints. The RAND Journal of Economics, 24(3), 328-342. https://doi.org/10.2307/2555961

Ferreira, M.A., \& Vilela, A.S. (2004). Why Do Firms Hold Cash? Evidence from EMU Countries. European Financial Management, 10(2), 295-319. https://doi.org/10.1111/j.1354-7798.2004.00251.x

García-Teruel, P.J., \& Martínez-Solano, P. (2008). On the Determinants of SME Cash Holdings: Evidence from Spain. Journal of Business Finance \& Accounting, 35(1-2), 127-149. https://doi.org/10.1111/j.1468-5957.2007.02022.x

Guney, Y., Ozkan, A., \& Ozkan, N. (2007). International Evidence on the Non-Linear Impact of Leverage on Corporate Cash Holdings. Journal of Multinational financial management, 17(1), 45-60. https://doi.org/10.1016/j.mulfin.2006.03.003

Harford, J., Mansi, S.A., \& Maxwell, W.F. (2008). Corporate Governance and Firm Cash Holdings in the US. Journal of Financial Economics, 87(3), 535-55. https://doi.org/10.1016/j.jfineco.2007.04.002

Harris, M., \& Raviv, A. (1990). Capital Structure and the Informational Role of Debt. The Journal of Finance, 45(2), 321-349. https://doi.org/10.1111/j.1540-6261.1990.tb03693.x

Jensen, M.C. (1986). Agency Cost of Free Cash Flow, Corporate Finance, and Takeovers. American Economic Review, 76(2), 323-329.

Kalcheva, I., \& Lins, K.V. (2007). International Evidence on Cash Holdings and Expected Managerial Agency Problems. Review of Financial Studies, 20(4), 1087-1112. https://doi.org/10.1093/rfs/hhm023

Keynes, J.M. (1936). General Theory of Employment, Interest and Money. Atlantic Publishers \& Dist. 
Kim, C.-S., Mauer, D.C., \& Sherman, A.E. (1998). The Determinants of Corporate Liquidity: Theory and Evidence. Journal of Financial and Quantitative Analysis, 33(3), 335-359. https://doi.org/10.2307/2331099

Kuan, T.-H., Li, C.-S., \& Chu, S.-H. (2011). Cash Holdings and Corporate Governance in Family-Controlled Firms. Journal of Business Research, 64(7), 757-64. https://doi.org/10.1016/j.jbusres.2010.07.004

Myers, S.C. (1977). Determinants of Corporate Borrowing. Journal of Financial Economics, 5(2), 147-175. https://doi.org/10.1016/0304-405X(77)90015-0

Myers, S.C. (1984). The Capital Structure Puzzle. The Journal of Finance, 39(3), 574-592. https://doi.org/10.1111/j.1540-6261.1984.tb03646.x

Myers, S.C., \& Majluf, N.S. (1984). Corporate Financing and Investment Decisions When Firms Have Information that Investors do not Have. Journal of Financial Economics, 13(2), 187-221. https://doi.org/10.1016/0304-405X(84)90023-0

Myers, S.C., \& Rajan, R.G. (1998). The Paradox of Liquidity. The Quarterly Journal of Economics, 113(3), 733-771. https://doi.org/10.1162/003355398555739

Opler, T., Pinkowitz, L., Stulz, R., \& Williamson, R. (1999). The Determinants and Implications of Corporate Cash Holdings. Journal of Financial Economics, 52(1), 3-46. https://doi.org/10.1016/S0304-405X(99)00003-3

Ozkan, A., \& Ozkan, N. (2004). Corporate Cash Holdings: An Empirical Investigation of UK Companies. Journal of Banking \& Finance, 28(9), 2103-2134. https://doi.org/10.1016/j.jbankfin.2003.08.003

Pinkowitz, L., \& Williamson, R. (2001). Bank Power and Cash Holdings: Evidence from Japan. Review of Financial Studies, 14(4), 1059-1082. https://doi.org/10.1093/rfs/14.4.1059

Smith, C.W., \& Warner, J.B. (1979). On Financial Contracting: An Analysis of Bond Covenants. Journal of Financial Economics, 7(2), 117-161. https://doi.org/10.1016/0304-405X(79)90011-4

Sufi, A. (2009). Bank Lines of Credit in Corporate Finance: An Empirical Analysis. Review of Financial Studies, 22(3), 1057-1088. https://doi.org/10.1093/revfin/hhm007

Titman, S., \& Wessels, R. (1988). The Determinants of Capital Structure Choice. The Journal of Finance, 43(1), 1-19. https://doi.org/10.1111/j.1540-6261.1988.tb02585.x

Uyar, A., \& Kuzey, C. (2014). Determinants of Corporate Cash Holdings: Evidence from the Emerging Market of Turkey. Applied Economics, 46(9), 1035-1048. https://doi.org/10.1080/00036846.2013.866203

Wooldridge, J.M. (2002). Econometric Analysis of Cross Section and Panel Data. MIT press. 